\title{
Planejamento, desenvolvimento e avaliação de um CURSo de FORMAÇÃO CONTINUADA PARA IMPLEMENTAÇÃO DA TEMÁTICA HISTÓRIA E CULTURA AFRO-BRASILEIRA NOS CURRÍ́CULOS ESCOLARES
}

\author{
PLANNING, DEVELOPMENT, AND EVALUATION OF A CONTINUING EDUCATION COURSE TO \\ IMPLEMENT THE AFRO-BRAZILIAN HISTORY AND CULTURE THEME IN SCHOOL \\ CURRICULA
}

PLANIFICACIÓN, DESARROLLO Y EVALUACIÓN DE UN CURSO DE FORMACIÓN CONTINUA PARA LA IMPLEMENTACIÓN DEL TEMA HISTORIA Y CULTURA AFROBRASILEÑA EN LOS PROGRAMAS ESCOLARES

\section{Leida Corrêa da Silva (iD) 9}

Mestrado em Ensino para a Educação Básica (IF Goiano) Professora efetiva da Secretaria de Estado da Educação de Goiás leida.silva@seduc.go.gov.br

Leandra Aparecida Mendes dos Santos Rodrigues

\section{iD 9}

Mestrado em Ensino para a Educação Básica (IF Goiano) Professora efetiva da Secretaria de Estado da Educação de Goiás leandra.aparecida@hotmail.com

\section{Mayara Lustosa de Oliveira Barbosa (iD) 9}

Doutorado em Biologia Celular e Estrutural (Unicamp) Professora EBTT no Instituto Federal de Brasília (IFB) Docente no Programa de Mestrado Profissional em Ensino para Educação Básica (IF Goiano) mayara.barbosa@ifb.edu.br

\section{Cristiane Maria Ribeiro}

\section{iD 9}

Doutorado em Educação (Ufscar) Docente no Programa de Mestrado Profissional em Ensino para Educação Básica (IF Goiano) cristiane.maria@ifgoiano.edu.br

\begin{abstract}
Resumo
Este estudo teve como objetivo planejar, desenvolver e avaliar um curso de formação continuada para professores do Ensino Fundamental I das escolas de Pires do Rio, estado de Goiás, mediante uma sequência didática que utiliza a Literatura Infantil para a socialização da Lei ${ }^{\circ} 10.639 / 03$. Trata-se de uma pesquisa aplicada, descritiva e exploratória, com uma abordagem qualiquantitativa dos dados. Como resultados do planejamento, o artigo traz uma metassíntese qualitativa de pesquisas obtidas por meio de uma revisão sistemática de literatura, com vistas a realizar um levantamento e analisar o que tem sido produzido na área da formação docente para as relações étnico-raciais, identificando aspectos que poderiam ser implementados na proposta do curso. No desenvolvimento do curso, foram utilizados como instrumentos para o levantamento de dados a observação-participante e três questionários aos docentes participantes, dois antes e outro após o curso. Os resultados apontaram a necessidade de cursos para a formação continuada dos docentes e do desenvolvimento de recursos baseados em evidências, tal como a Sequência Didática baseada no uso da Literatura Infantil como forma de implementação da Lei $n^{\circ}$ 10.639/03.
\end{abstract}

Palavras-chave: Formação Continuada. Relações ÉtnicoRaciais. Lei $n^{\circ}$ 10.639/03. Sequência Didática.

Recebido em: 4 de março de 2021.

Aprovado em: 21 de abril de 2021.

Como citar esse artigo (ABNT):

SILVA, Leida Corrêa da et al. Planejamento, desenvolvimento e avaliação de um curso de formação continuada para implementação da temática História e Cultura Afro-Brasileira nos currículos escolares. Revista Prática Docente, v. 6, n. 1, e024, 2021.

http://doi.org/10.23926/RPD.2021.v6.n1.e024.id1032 
Revista Prática Docente (RPD)

ISSN: 2526-2149 


\section{Abstract}

This study aimed to plan, develop and evaluate a continuing education course for teachers of Elementary School I of the schools of Pires do Rio, state of Goiás, through a didactic sequence that uses Children's Literature for the socialization of Law 10.639/03. This is an applied, descriptive and exploratory research, with a quali-quantitative approach to the data. As planning results, the article brings a qualitative meta-synthesis of research obtained through a systematic literature review, in order to survey and analyze what has been produced in the area of teacher training for ethnic-racial relations, identifying aspects that could be implemented in the course proposal. During the development of the course, we used participant observation and three questionnaires to the participating teachers, two before and one after the course. The results indicated the need for continued education courses for teachers and the development of evidencebased resources, such as the Teaching Sequence based on the use of Children's Literature as a way to implement Law 10.639/03.

Keywords: Teacher Training.Ethnic Racial Relations.Law $\mathrm{n}^{\circ}$ 10.639/03.Didactic Sequence.

\section{Resumen}

Este estudio tuvo como objetivo planificar, desarrollar y evaluar un curso de formación continua para profesores de la Escuela Primaria I de las escuelas de Pires do Rio, estado de Goiás, a través de una secuencia didáctica que utiliza la Literatura Infantil para la socialización de la Ley $\mathrm{n}^{\circ} 10.639 / 03$. Se trata de una investigación aplicada, descriptiva y exploratoria, con un enfoque cuali-cuantitativo de los datos. Como resultados de la planificación, el artículo trae una metasíntesis cualitativa de la investigación obtenida a través de una revisión sistemática de la literatura, con el fin de realizar un estudio y analizar lo que se ha producido en el ámbito de la formación de profesores para las relaciones étnico-raciales, identificando los aspectos que podrían ser implementados en la propuesta de curso. En el desarrollo del curso, se utilizaron como instrumentos de recogida de datos la observación participante y tres cuestionarios a los profesores participantes, dos antes y uno después del curso. Los resultados indicaron la necesidad de cursos de formación continua para los profesores y el desarrollo de recursos basados en la evidencia, como la Secuencia Didáctica basada en el uso de la Literatura Infantil como forma de aplicar la Ley $n^{\circ} 10.639 / 03$.

Palabras clave: Educación continua. relaciones étnico-raciales. Ley $n^{\circ} 10.639$ / 03. Secuencia Didáctica. 


\section{INTRODUÇÃo}

Em 2018, um terço dos brasileiros entre 19 e 24 anos não concluíram o Ensino Médio (FOLHA DE SÃO PAULO, 2019). Essa média geral é similar entre jovens brancos, mas o panorama entre negros é pior: quase metade $(44,2 \%)$ dessa faixa etária não concluiu o Ensino Médio. Desse modo, é perceptível que o processo de formação educacional básica, no Brasil, não tem como característica acolher de modo equânime a população, aumentando, assim, a chance de exclusão escolar dos negros ao longo da educação básica.

Essa realidade identificada nas escolas brasileiras evidencia que muitos alunos negros abandonam os estudos e pesquisadores demonstram que essa questão pode ser consequência do racismo estrutural e institucional (ALMEIDA, 2018). Neste contexto, estudantes brancos têm mais acesso e permanência ao Ensino Médio, mesmo analisando as variáveis gênero, idade, renda per capita e região (TAVARES JÚNIOR et al., 2015).

Outro fato notório é o de que a discriminação no contexto escolar possui longevidade histórica. Segundo Florestan Fernandes (1972), o racismo no Brasil é uma sobrevivência da escravidão, e o comportamento racista é praticado pela maioria dos brasileiros, embora essas pessoas não admitam cometer tais ações, expressando um racismo sem rosto, uma espécie de preconceito reativo: “o preconceito de ter preconceito”. Isso também é corroborado por Freitag e Winkler (2014), ao afirmarem que a escravidão desapareceu como instituição, mas ficou como existência cultural.

A fim de romper com o eurocentrismo (ideia de que a Europa é o centro da cultura do mundo) e o ensino monocultural (que privilegia um único grupo étnico-racial, o qual é apresentado como legítimo, sendo os demais percebidos como inferiores) os quais privilegiam a cultura europeia, a Lei ${ }^{\circ}$ 10.639/03 foi promulgada com o objetivo de promover o ensino da "História da África e dos Afro-Brasileiros" nos currículos escolares. Em 2008, foi também promulgada a Lei 11.645, a qual altera a Lei ${ }^{\circ} 10.639 / 03$ e inclui a valorização e a inclusão da cultura indígena no currículo escolar. A 11.645 estabelece em seu "Art. 26-A. Nos estabelecimentos de ensino fundamental e de ensino médio, públicos e privados, torna-se obrigatório o estudo da história e cultura afro-brasileira e indígena" (BRASIL, 2008, p. 1). Como altera apenas um dos parágrafos da 10.639/03, as Leis continuam sendo tratadas conjuntamente (CARTH, 2017).

Para esse estudo, mesmo a Lei $\mathrm{n}^{\circ} 10.639 / 03$ sendo alterada em 2008 pela Lei ${ }^{\circ} 11.645$, ainda foi mantida a análise sob sua implementação, por se tratar de um marco legislativo na 
conquista pela inserção do ensino sobre História e Cultura Afro-Brasileira no âmbito de todo o currículo escolar. A implementação da Lei $n^{\circ}$ 10.639/03 foi fundamental, pois, como citado anteriormente, pertencemos a uma estrutura social racista e, desde muito cedo, são incutidos em nós crenças, valores e estereótipos negativos sobre o negro e sua cultura, os quais, se não forem desconstruídos, seguirão sendo reproduzidos por várias outras gerações (ARAÚJO; MORAIS, 2014). Desse modo, o contato com a cultura africana na sala de aula pode desmistificar o tratamento preconceituoso dispensado ao negro e ressignificar a cultura negra, revertendo o abandono das raízes negras pelos seus descendentes (FREITAG; WINKLER, 2014).

Nessa linha, a literatura pode ser um instrumento significativo e de amplo alcance na formação das mentes infantis e juvenis (COELHO, 2000). Pode ser um componente básico para o desenvolvimento da subjetividade da criança, permitindo que, por meio da imaginação, seja exercitada a capacidade de resolução de problemas (ZILBERMAN, 2003). Ademais, a literatura pode ser um caminho de interpretação da vida humana (PERISSÉ, 2006). Sendo assim, contribui para a formação social na educação, pois, a pesquisa e a leitura de obras comprometidas com a afirmação do afrodescendente e de sua cultura podem ser um caminho a ser trilhado pelos profissionais da educação na contemplação da diversidade (PEIXOTO, 2013).

Aspectos como o desconhecimento da Lei $\mathrm{n}^{\circ}$ 10.639/03 e das diretrizes curriculares sobre a temática inviabilizam o planejamento de atividades didáticas voltadas para a temática (RODRIGUES et. al., 2010). Para desenvolverem as determinações da Lei $n^{\circ}$ 10.639/03, bem como utilizarem a literatura para esse processo, os profissionais da educação precisam estar sensibilizados e preparados. Portanto, faz-se necessária a formação de professores, não só para discutir as questões raciais, mas para criar e implementar ações que possibilitem o trabalho com a diversidade cultural (CANEN; XAVIER, 2011).

Pensando na prática educativa dos docentes objetivou-se oferecer uma formação continuada, baseada em uma Sequência Didática, que utiliza a literatura para ensino da história e cultura afro-brasileira. Para Zabala (1998), as Sequências Didáticas são um conjunto de atividades ordenadas, estruturadas e articuladas, a fim de alcançar objetivos educacionais. As Sequências Didáticas tornam a aprendizagem mais significativa e permitem aos professores um planejamento sistemático de atividades para o trabalho com a diversidade.

Apesar de o foco do panorama teórico apresentado até o momento restringir-se à formação docente e ao emprego de Sequências Didáticas, ressalta-se que, para o 
estabelecimento de qualquer pesquisa bem consolidada, é necessário analisar qual foi o caminho percorrido pelos pesquisadores até o momento (TEIXEIRA; MEGID NETO, 2012). Tal procedimento ajuda a evitar a repetição de resultados sem implicações, bem como em propor alternativas que sejam realmente aplicáveis e úteis. Em outras palavras, ter como base os erros e acertos cometidos por outros pesquisadores da área é fundamental para não repetir as mesmas intercorrências e buscar inovações.

Nesse sentido, é fácil notar que tanto a formação docente, quanto o próprio uso de Sequências Didáticas, são campos vastos em produções publicadas. Mas, e quanto à Lei $\mathrm{n}^{\circ}$ 10.639/03, o que tem sido produzido na perspectiva de sua implementação e socialização? As produções têm relação com a formação docente? E com o uso de Sequências Didáticas?

Diante deste cenário, a presente pesquisa teve como objetivos gerais planejar, desenvolver e avaliar um curso de formação continuada, utilizando uma Sequência Didática e a Literatura Infantil para a socialização da Lei no 10.639/03. Para tanto, inicialmente, foi realizada uma revisão sistemática de literatura em busca de: 1) encontrar propostas que relacionem a formação docente e a Lei no 10.639/03; 2) analisar os trabalhos, de modo a propor um curso consistente com as evidências de sucesso encontradas na literatura; e 3) construir uma proposta com ineditismo, coerência e aplicabilidade prática. Posteriormente, o curso de formação foi desenvolvido e avaliado.

A seguir, são descritas todas as etapas desenvolvidas no percurso metodológico da pesquisa, bem como os resultados desde o planejamento até a finalização do curso.

\section{Metodologia}

\subsection{CaracterizaÇÃo da PESQUisa}

Esta pesquisa tem caráter descritivo-exploratório, pois objetiva descrever um curso em seu contexto, bem como adquirir familiaridade e informações mais profundas, a partir do registro, análise e interpretação dos fenômenos associados ao curso (RODRIGUES, 2006). Apresenta uma abordagem quali-quantitativa, pois visa à análise de dados, traduzindo, em números, as informações coletadas nos questionários, além de buscar interpretar as opiniões, comportamentos, intenções, os quais não podem ser mensurados de modo numérico (MARCONI; LAKATOS, 2018). Em relação à natureza, trata-se de uma pesquisa aplicada, pois intenciona a utilização dos resultados para solucionar problemas da realidade (MARCONI; LAKATOS, 2018). 


\subsection{PARÂMETROS da ReVisÃo Sistemática de Literatura}

Para realizar a revisão sistemática de literatura, as pesquisadoras acessaram as principais bases de dados disponíveis (Scopus, Web of Science, Scielo e Google Scholar). O objetivo principal desse processo foi encontrar artigos relacionados à temática proposta.

As três primeiras bases foram escolhidas devido à abrangência quanto ao número de publicações e qualidade das revistas científicas indexadas. A última base foi adicionada devido ao fato de que a pesquisa abarca como palavra-chave uma Lei Nacional, e o Google Scholar ofereceria resultados mais relacionados com a proposta da presente pesquisa.

Todas as bases utilizadas permitiram a exploração em profundidade de áreas especializadas por meio do mecanismo de pesquisa avançada. Para tanto, em todas as bases, pesquisaram-se pelas seguintes palavras-chave, considerando os idiomas inglês e português: "formação docente", "sequência didática" e "Lei 10.639". O período delimitado nas buscas contemplou 16 anos, ou seja, de 2003 (ano de promulgação da Lei) a 2019 (apenas o primeiro semestre foi considerado, antes da realização do curso de formação). Em nenhuma das bases foram encontrados artigos com todas as palavras correspondentes no título, nas palavras-chaves e nos resumos, no período estabelecido. Mas, ao separar as palavras, foram encontradas diversas pesquisas. As demais tentativas e a quantidade de artigos encontrados são descritos na Tabela 1.

Tabela 1 - Palavras utilizadas na pesquisa e resultados encontrados em cada uma das bases

\begin{tabular}{l|lc}
\hline Base de Dados & \multicolumn{1}{|c|}{ Palavras da Pesquisa Avançada } & Quantidade de Pesquisas \\
\hline \multirow{2}{*}{ Scopus } & TITLE-ABS-KEY (teacher* training AND law 10.639) & 4 \\
& TITLE-ABS-KEY (didactic sequence AND law 10.639) & 0 \\
\hline \multirow{2}{*}{ Web of Science } & TS = (teacher* training AND law 10.639) & 15 \\
& TS = (didactic sequence AND law 10.639) & 0 \\
\hline \multirow{5}{*}{ Scielo } & formação docente lei 10.639 & 1 \\
& formação professores lei 10.639 & 7 \\
& teacher training law 10.639 & 3 \\
& sequência didática lei 10.639 & 0 \\
& didactic sequence law 10.639 & 0 \\
\hline \multirow{5}{*}{ Google Scholar } & allintitle: teacher training law 10.639 & 1 \\
& allintitle: formação docente lei 10.639 10.639 formação professores lei 10.639 & 12 \\
& allintitle: didactic sequence law 10.639 & 31 \\
& allintitle: sequência didática leis 10.639 & 0 \\
\hline & Total de pesquisas encontradas & 1 \\
\hline
\end{tabular}

Fonte: Elaborada pelas autoras a partir da busca avançada em cada uma das bases (2020). 
O método da metassíntese qualitativa foi aplicado para analisar os artigos encontrados na revisão, de modo a obter informações sobre o caminho percorrido pelos pesquisadores até o momento, evitar a repetição de resultados sem implicações e propor alternativas que sejam realmente aplicáveis e úteis na formação de professores. A técnica é, em geral, empregada em associação com a revisão sistemática de literatura, sendo definida como a integração e síntese interpretativa dos dados dos artigos que compõem a amostra (ALENCAR; ALMOULOUD, 2017; MATHEUS, 2009). O objetivo da técnica é justamente tornar os resultados das pesquisas primárias mais acessíveis para serem estudados e relacionados, permitindo compará-los e revelar as convergências, a fim de alcançar uma análise teórica mais sintética, ao mesmo tempo em que é robusta e integrada (MATHEUS, 2009).

Tais estudos promovem a apresentação das contribuições das pesquisas, permitem uma avaliação do que foi produzido academicamente na área, identificando as possíveis tendências e pontos frágeis que precisam ser aprofundados, assim como resumem as principais ideias e obras do tema investigado (VOSGERAU; ROMANOWSKI, 2014). Reforça-se que, para uma visão interpretativa abrangente, é preciso que os resultados encontrados nas análises sejam agrupados por semelhanças, na tentativa de responder às questões que nortearam a pesquisa (VOSGERAU; ROMANOWSKI, 2014). Esse foi o procedimento adotado em nossa análise.

As etapas da metassíntese seguiram as descritas por Matheus (2009), baseando-se na proposta do UK Cochrane Centre, uma iniciativa internacional com origem no Reino Unido, a qual prepara, mantém e dissemina revisões sistemáticas desde 1922. As etapas estão descritas, a seguir, bem como o que foi feito no artigo para atender a cada uma delas.

1) Identificação do objetivo ou das questões que irão nortear a revisão: os dados recolhidos a partir dos artigos buscavam responder: 1) quais propostas têm sido apresentadas na relação formação docente e a Lei $\mathrm{n}^{\circ} 10.639 / 03$ ?; 2) quais objetivos e principais conclusões dos trabalhos? e 3) existem Sequências Didáticas resultantes de alguma dessas pesquisas com o uso da Lei?

2) Definição dos critérios de inclusão ou elegibilidade, selecionando pesquisas que são relevantes aos interesses do levantamento: os critérios foram a) apenas artigos científicos, excluindo outras modalidades de publicação; b) artigos publicados a partir de 2003 até 2019; c) artigos com disponibilidade de texto completo em suporte eletrônico; d) artigos empíricos ou de revisão cuja temática estivesse centrada na formação docente e na Educação das Relações Étnico-Raciais; e) apenas aqueles publicados em periódicos cujo 
critério de avaliação seja a revisão por pares, de modo a obter resultados mais consubstanciados; e f) artigos publicados em inglês ou português. Ressalta-se que foram removidos artigos que apenas citavam a formação docente ou a Lei n $10.639 / 03$, mas não tinham relação direta com os temas.

3) Realização da leitura dos estudos, elaborando resumos de forma a tornar os resultados mais acessíveis e organizados: os trabalhos foram lidos e a síntese de seus conteúdos estruturada em uma tabela que menciona: o título, o ano, os autores, o periódico, os objetivos, os resultados e as principais conclusões.

4) Determinação de como os estudos se relacionam justapondo os dados; e

5) Elaboração de afirmações concisas e amplas que correspondam ao conteúdo do conjunto dos resultados: os objetivos e conclusões foram justapostos e apresentados, de modo separado, a partir das convergências apresentadas. Para tanto, afirmações concisas e amplas, abordando aspectos essenciais dos artigos, foram definidas para cada tópico (objetivo e conclusão), apresentando a essência do conjunto de dados para cada base, assim como as conclusões que têm implicações mais específicas para este trabalho.

6) Elaboração de uma proposta sintética e robusta equivalente a todos os estudos pesquisados: por fim, estabeleceu-se uma conclusão em resposta aos questionamentos expostos na etapa 1 , incluindo aspectos contidos nos estudos pesquisados, o que permitiu justificar os esforços de nossa pesquisa, além de identificar áreas ainda não cobertas pelos pesquisadores e desenhar uma proposta inédita de curso com uso de uma Sequência Didática.

\subsection{Público-Alvo e MÉTOdos de aVAliaÇão da PROPOSTA}

Após o levantamento bibliográfico e a verificação das temáticas até então trabalhadas por meio da metassíntese qualitativa, foram realizadas reuniões com a Secretaria Municipal de Educação (SME) e Coordenação Regional de Educação Estadual (CRE) do município de Pires do Rio, estado de Goiás (GO), visando apresentar a proposta do curso de formação continuada.

Nessas reuniões, foram estabelecidas as turmas (séries) do Ensino Fundamental I que seriam contempladas ( $4^{\circ}$ e $5^{\circ}$ anos), o local do minicurso e a garantia de representação de todas as Unidades Educacionais. A proposta se estruturou como um curso de curta duração vinculado ao programa de Extensão no Instituto Federal Goiano - Campus Urutaí.

Reforça-se que, para garantir essa representatividade, foi solicitado, no momento da inscrição, que deveria haver pelo menos um(a) professor(a) representante de cada Unidade 
Educacional pública do município de Pires do Rio, a fim de que gerasse impacto na formação continuada dos professores desse município.

Assim, participaram da pesquisa 23 professoras de $4^{\circ}$ e $5^{\circ}$ anos do Ensino Fundamental I. O número de participantes é significativo, já que contempla o número total de professores de todas as dez Unidades Educacionais públicas desta etapa de ensino do município de Pires do Rio. Destas, duas instituições são da rede estadual de ensino.

Para ter uma visão mais ampla dos participantes, foi aplicado um primeiro questionário para o levantamento dos dados iniciais de identificação, em seguida foi aplicado um segundo questionário (pré-curso) para sondagem dos conhecimentos prévios dos professores em relação à Lei no 10.639/03 e à sua aplicabilidade e, ao final, foi aplicado um terceiro questionário (póscurso), verificando os conteúdos aprendidos e a relevância da formação continuada.

Os dois questionários finais (pré-curso e pós-curso) possuíam perguntas similares, contudo, foi adicionado ao último deles três questões com itens em escala Likert (DALMORO; VIEIRA, 2013). A escala atitudinal foi acrescentada de modo a verificar a satisfação dos participantes com relação ao curso, à aplicabilidade e à relevância da proposta.

Outro método também utilizado durante o desenvolvimento da proposta foi a observação-participante, abordagem utilizada com interesse em dados como a dinâmica, as interações e reações do grupo participante diante das propostas. Além disso, esse método interessa pela obtenção de informações adicionais e relevantes do contexto e das impressões dos sujeitos, as quais as entrevistas e questionários, muitas vezes, não conseguem captar (SMITH; DENTON, 2001; STRAND; OLIN; TIDEFORS, 2015).

\section{Resultados}

\subsection{Resultados da Revisão Sistemática de Literatura e da metassíntese QUALITATIVA}

Como apresentado na tabela 2, por meio da busca nas três bases de dados foram recuperados 75 artigos, porém aplicando os critérios de elegibilidade entraram na análise 39 artigos, pois 36 não se enquadraram nos critérios previamente definidos. 
Tabela 2 - Quantitativo de artigos recuperados e quantitativo de artigos analisados

\begin{tabular}{|c|c|c|}
\hline Bases de Dados & Artigos recuperados das bases & Artigos incluídos na análise \\
\hline Scopus & 4 & 4 \\
\hline Web Of Science & 15 & 13 \\
\hline Scielo & 11 & 6 \\
\hline Google Scholar & 45 & 16 \\
\hline Total & 75 & 39 \\
\hline
\end{tabular}

Fonte: Elaborada pelas autoras com base nos dados da pesquisa (2020).

Após aplicar os critérios de inclusão e a sequência das etapas da metassíntese, foram selecionados os artigos a serem analisados em cada base de dados e destacou-se o objetivo de cada uma das produções. Como pode ser observado no quadro 1.

Quadro 1 - Artigos analisados em cada base de dados e seus objetivos

\begin{tabular}{|c|c|c|}
\hline Bases & Autores dos artigos & Objetivo dos artigos \\
\hline Scopus & $\begin{array}{l}\text { PEREIRA et al., 2018; GILLAM, } \\
\text { 2016; GUIMARÃES, 2015; } \\
\text { SULEIMAN, } 2014 .\end{array}$ & $\begin{array}{l}\text { Analisam o conhecimento e a implementação da Lei } \mathrm{n}^{\circ} \\
10.639 / 03 \text { por parte dos docentes, bem como verificam o efeito } \\
\text { dos cursos de formação continuada na mudança de concepções } \\
\text { dos participantes. }\end{array}$ \\
\hline \multirow{4}{*}{$\begin{array}{l}\text { Web of } \\
\text { Science }\end{array}$} & $\begin{array}{l}\text { CARDOSO et al., 2016; CESAR; } \\
\text { LIMA, 2018; MARTINS, 2016; } \\
\text { PEREIRA et al., } 2016 .\end{array}$ & $\begin{array}{l}\text { Descrevem e refletem sobre experiências de pesquisa e } \\
\text { formação de professores (inicial e continuada), no sentido de } \\
\text { contribuir para a inclusão da história e cultura afro-brasileira, } \\
\text { africana e indígena na educação formal. }\end{array}$ \\
\hline & $\begin{array}{l}\text { DAXENBERGER, 2017; } \\
\text { FAVACHO } \text { et al., 2017; SILVA; } \\
\text { OLIVEIRA, 2015. }\end{array}$ & $\begin{array}{l}\text { Avaliam se a Lei está sendo implementada e como está se } \\
\text { constituindo a educação para as relações étnico-raciais nas } \\
\text { escolas. }\end{array}$ \\
\hline & $\begin{array}{l}\text { CARDOSO; CASTRO, 2015; } \\
\text { COSTA; CUSTÓDIO, 2015; } \\
\text { LIMA; COSTA, 2014; } \\
\text { MARQUES, 2017; SOUZA, } 2016 .\end{array}$ & $\begin{array}{l}\text { Apresentam as mudanças que a Lei } \mathrm{n}^{\circ} 10.639 / 03 \text { provocou no } \\
\text { currículo, nas ementas e livros didáticos, e os desafios práticos } \\
\text { da descolonização e efetivação de práticas pedagógicas } \\
\text { interculturais. }\end{array}$ \\
\hline & SILVA, 2018. & $\begin{array}{l}\text { Cataloga e inventaria o patrimônio cultural afro banto } \\
\text { brasileiro, visando à inclusão da sua história, cultura e } \\
\text { religiosidade nos currículos escolares. }\end{array}$ \\
\hline \multirow{3}{*}{ Scielo } & $\begin{array}{l}\text { BENITE } \text { et al., 2018; COELHO; } \\
\text { COELHO, 2013; OLIVEIRA, } 2013\end{array}$ & $\begin{array}{l}\text { Relata o desenvolvimento de intervenções pedagógicas e } \\
\text { avaliação destas. }\end{array}$ \\
\hline & $\begin{array}{l}\text { COELHO; COELHO, 2018; } \\
\text { OLIVEIRA; SILVA, } 2017 .\end{array}$ & $\begin{array}{l}\text { Analisam a formação inicial a partir dos trajetos curriculares de } \\
\text { cursos oferecidos por universidades federais, e da construção de } \\
\text { sentidos na educação étnico-racial de professores em formação } \\
\text { inicial. }\end{array}$ \\
\hline & PAULA; GUIMARÃES, 2014. & $\begin{array}{l}\text { Examina a produção científica de dez anos a partir da entrada } \\
\text { da Lei em vigor. }\end{array}$ \\
\hline \multirow{2}{*}{$\begin{array}{l}\text { Google } \\
\text { Scholar }\end{array}$} & $\begin{array}{l}\text { AMÉRICO, 2011; AMÉRICO, } \\
\text { 2014; AMÉRICO; LUIZ, 2010; } \\
\text { DIAS; CECATTO, 2015; } \\
\text { EUGENIO; SANTANA, 2018; } \\
\text { MARQUES, 2017; SILVA; } \\
\text { MARQUES, 2015. }\end{array}$ & $\begin{array}{l}\text { Apresentam relatos de pesquisa, valorizando as experiências } \\
\text { vividas pelos sujeitos em seus contextos e identificando os } \\
\text { desafios enfrentados para a implementação da Lei n }{ }^{\circ} 10.639 / 03 \text {, } \\
\text { bem como os limites impostos pelas políticas públicas. }\end{array}$ \\
\hline & $\begin{array}{l}\text { ALVES, 2017; GARCIA et al., } \\
\text { 2012; LIRIO, 2015; MOREIRA, } \\
\text { 2016; MÜLLER; COELHO, 2013; } \\
\text { OLIVEIRA, 2013; SOARES, 2017; } \\
\text { VIÇOSA; GODOY, } 2017 .\end{array}$ & $\begin{array}{l}\text { Descrevem os eventos históricos que culminaram na } \\
\text { formulação da Lei e as ações desencadeadas a partir dos marcos } \\
\text { legislativos, apontando os desafios enfrentados para a } \\
\text { democratização do currículo e a necessidade de cursos de } \\
\text { especialização e formação continuada na área, tendo em vista } \\
\text { as lacunas presentes no contexto acadêmico. }\end{array}$ \\
\hline
\end{tabular}


Fonte: Elaborada pelas autoras com base nos dados da pesquisa (2020).

Na base de dados Scopus, destacamos o trabalho de Suleiman (2014), que apresentou a Lei $\mathrm{n}^{\circ} 10.639 / 03$ por meio de uma oficina, buscando proporcionar reflexões aos docentes acerca da invisibilidade do ensino da história do negro no Brasil, incluindo exemplos da Literatura Infantil e infanto-juvenil. Por se tratar de um artigo curto publicado em uma seção de "Relato de Práticas Profissionais", não há descritivo de detalhes a respeito da abordagem no uso da literatura. Contudo, as conclusões da pesquisa demonstram que houve aceitação por parte do público-alvo, visto que a autora afirma que foram atingidos os objetivos da pesquisa e a avaliação por parte dos docentes foi positiva (SULEIMAN, 2014).

Por meio das conclusões dos trabalhos, foi possível identificar que: 1) a maioria dos professores não sabe do que trata a Lei; e 2) apesar dos avanços e iniciativas do governo, é preciso dar uma maior atenção à formação de professores, pois o espaço da sala de aula é extremamente propício para o reconhecimento do racismo (GILLAM, 2016; GUIMARÃES, 2015; PEREIRA et al., 2018).

Ao tabularmos os quinze artigos encontrados na base Web of Science, foi possível observar que dois deles já haviam sido analisados na base anterior, Gillam (2016) e Guimarães (2015), entrando na análise apenas treze artigos. Em relação às conclusões dos trabalhos desta base, é apontado que a abordagem das relações étnico-raciais, visando a superação do racismo na escola, tem sido feita de maneira descontextualizada, pontual e incipiente, devido à falta de formação da comunidade escolar na referida área de conhecimento, sendo de extrema importância a implementação de políticas públicas que possibilitem o desenvolvimento de programas de formação inicial e continuada (CARDOSO et al., 2016; COSTA; CUSTÓDIO, 2015; DAXENBERGER, 2017; FAVACHO et al., 2017; MARTINS, 2016;). Além de apresentarem conclusões semelhantes às apontadas para os trabalhos analisados na base anterior, a resistência de alguns docentes no lidar com as questões raciais também é apontada como desafio no cenário educacional (MARQUES, 2017; PEREIRA et al., 2016).

As conclusões mais relevantes para o foco de nossa pesquisa estão nos trabalhos de Cesar e Lima (2018) e Silva e Oliveira (2015). Os primeiros reforçam que um dos melhores modos de trabalhar no sentido da superação do colonialismo é valorizando o conhecimento disponível na cultura, a começar pelo aumento na visibilidade de mulheres negras na literatura. 
Silva e Oliveira (2015), por sua vez também fazem uso da literatura e de representações pessoais no estímulo da valorização da beleza negra.

$\mathrm{Na}$ Scielo, foram encontrados 11 artigos, entretanto, como a pesquisa utilizava palavras semelhantes em idiomas diferentes na mesma base (Tabela 1), alguns deles foram repetidos nas sucessivas buscas, ou já haviam sido analisados, como é o caso de Suleiman (2014). Sendo assim, foram encontrados seis trabalhos.

Com relação às conclusões com implicações relevantes para a presente pesquisa, destaca-se o artigo de Paula e Guimarães (2014) que teve por objetivo examinar a produção científica de dez anos a partir da entrada da Lei $n^{\circ}$ 10.639/2003 em vigor. Suas conclusões apontam que a formação continuada se torna basilar para a implementação da obrigatoriedade do estudo da história e da cultura africana e afro-brasileira, tendo em vista a formação inicial considerada lacunar ou mesmo insatisfatória neste campo. Nossa análise, a partir dos artigos supracitados, demonstra que a necessidade de formação continuada permanece, bem como as lacunas na formação inicial, o que reforça o fato de que iniciativas como a deste trabalho devem ser fomentadas.

Outro ponto relevante da pesquisa citada é o fato de que o Ensino Fundamental é foco de apenas dois estudos ao longo de todos os anos (PAULA; GUIMARÃES, 2014). Tal fato demonstrou um incentivo maior para a estruturação de nossa proposta e reforça a necessidade de pesquisas voltadas para esse público-alvo.

Outras conclusões que merecem ser destacadas são as de Benite e colaboradores (2018), os quais, por meio da intervenção pedagógica denominada "Ensino de Ciências e Identidade Negra: Estudos sobre a Química dos cabelos”, contribuíram para a operacionalização da Lei, por meio de estímulo ao diálogo, questionando discursos que reforçam as discriminações e os estereótipos. Tal iniciativa também foi utilizada como direcionadora, na escolha da literatura a ser trabalhada em nosso curso.

Na última base de dados analisada (Google Scholar), foram encontrados, a princípio, quarenta e cinco produções científicas dentre monografias, capítulos de livro, trabalhos de conclusão de curso lato sensu, dissertações e trabalhos apresentados em congressos. Entretanto, ao remover os trabalhos já analisados em outras bases e selecionar apenas artigos científicos de periódicos avaliados por pares, restaram 16 artigos.

Com relação ao contexto da presente pesquisa, ressalta-se que apenas um dos trabalhos estava relacionado com a aplicação de Sequência Didática. Esse trabalho foi desenvolvido por 
Alves-Brito e colaboradores (2018), e propõe uma Sequência Didática como estratégia para combater, em aulas de Ciências/Física, a discriminação étnico-racial. Para tanto, foram apresentados conceitos relacionados à astronomia cultural e como o céu e as constelações são denominadas em diferentes culturas. Assim, não foram encontradas propostas de construção e avaliação de Sequência Didática relacionadas à Literatura Infantil.

Com relação às principais conclusões, podemos apontar Eugênio e Santana (2018), os quais afirmam que a história da luta dos negros vem sendo excluída, especialmente no Ensino Fundamental, e que, no momento da contação de história, os heróis negros não são lembrados. Os autores concluem que a falta de visibilidade negra é um dos pontos que contribuem para a marginalização escolar de crianças e de jovens negros. Tal conclusão também se caracterizou como um estímulo para a estruturação do curso e do uso da literatura com personagens principais negros.

Dias e Cecatto (2015) destacam em suas conclusões que só a aprovação da Lei $\mathrm{n}^{\circ}$ 10.639/2003 não é o suficiente para que o trabalho docente ocorra em sala de aula e no interior das escolas, e que se deve oportunizar formação específica para os professores. Os autores apontaram que a precariedade e, na maioria das vezes, a ausência de materiais que discutem essa temática, assim como a insuficiência e limitação do livro didático, são alguns dos aspectos que dificultam a consolidação de propostas relacionadas à socialização da Lei.

O parco diálogo entre a escola e a universidade e a importância do desenvolvimento de práticas educativas que não tenham, como ponto de partida, a conotação deturpada da cultura africana são questões que merecem reflexão. Pois, é negado às crianças desde os anos iniciais a compreensão da contribuição do seu povo na produção cultural, artística e econômica de nosso país. Estas foram algumas conclusões que também trouxeram contribuições a esta pesquisa Américo, (2014), Américo e Luiz (2010), Müller e Coelho (2013) e Viçosa e Moreira (2016).

Pela análise dos dados expostos, foi possível inferir que, após 16 anos que a Lei entrou em vigor, ainda existem lacunas na formação inicial e que muitos docentes não se sentem preparados para lidar com as questões étnico-raciais. Assim, se o objetivo é a implementação da Lei, é necessário, unindo as inferências dos artigos de nossa amostra, atuar em três vertentes: 1) abordar a temática das relações étnico-raciais na formação inicial; 2) atuar na formação continuada; e 3) desenvolver e disponibilizar recursos didáticos, baseados em evidências, e que sejam adaptáveis aos currículos/ementas. 
Nesse sentido, além da necessidade de formação continuada, a abordagem superficial e enviesada de muitos livros didáticos, a escassez de recursos apresentada pelas pesquisas e o parco foco no Ensino Fundamental foram estímulos para o desenvolvimento da presente proposta, em especial, para a estruturação de uma Sequência Didática, tendo em vista facilitar a inclusão da história e cultura afro-brasileira e africana na educação básica. As análises dos trabalhos também serviram como direcionador na estruturação de uma proposta baseada em evidências, inédita e bem consolidada.

\subsection{Planejamento e Delineamento da Sequência Didática e do Curso de} FORMAÇÃo

Após o levantamento bibliográfico e a verificação das temáticas com resultados mais proeminentes, iniciou-se o planejamento e delineamento da Sequência Didática e do curso. Na etapa de planejamento, selecionaram-se dois livros a serem trabalhados: "A menina bonita do laço de fita", de Ana Maria Machado (2011) e "O lápis cor de pele do menino marrom”, de Ana Paula Marini (2018).

Em seguida, a elaboração da Sequência Didática foi fundamentada nas indicações oferecidas por Zabala (1998), a fim de construir propostas de atividades que contemplassem conteúdos conceituais, procedimentais e atitudinais adequados. A verificação dos conteúdos foi realizada respondendo aos seguintes questionamentos:

(...) na sequência didática existem atividades: a) que nos permitam determinar os conhecimentos prévios que cada aluno tem em relação aos novos conteúdos de aprendizagem? b) cujos conteúdos são propostos de forma que sejam significativos e funcionais para os meninos e meninas? c) que possamos inferir que são adequados ao nível de desenvolvimento de cada aluno? d) que representam um desafio alcançável para o aluno, quer dizer, que levam em conta suas competências atuais e as façam avançar com a ajuda necessária; portanto, que permitam criar zonas de desenvolvimento proximal e intervir? e) que provoquem um conflito cognitivo e promovam a atividade mental do aluno, necessária para que estabeleça relações entre os novos conteúdos e os conhecimentos prévios? f) que promovam uma atitude favorável, quer dizer, que sejam motivadoras em relação à aprendizagem dos novos conteúdos? g) que estimulem a autoestima e o autoconceito em relação às aprendizagens que se propõem, quer dizer, que o aluno possa sentir que em certo grau aprendeu, que seu esforço valeu a pena? h) que ajudem o aluno a adquirir habilidades relacionadas com o aprender a aprender, que lhe permitam ser cada vez mais autônomo em suas aprendizagens? (ZABALA, 1998, p. 63-64).

Com o objetivo de atender a cada um dos questionamentos estabelecidos por Zabala (1998), a Sequência Didática foi organizada em seis aulas (Quadro 2). 
Quadro 2 - Síntese da Sequência Didática

\begin{tabular}{|c|l|l|}
\hline Aulas & \multicolumn{1}{|c|}{ Conteúdo } & \multicolumn{1}{c|}{ Atividades propostas } \\
\hline 1 & Apresentação da proposta & $\begin{array}{l}\text { Organizar os alunos em um semicírculo; Distribuir livros de } \\
\text { literatura infantil que contemplem a cultura afro-brasileira e } \\
\text { africana; Ativar os conhecimentos prévios sobre o tema; Motivar } \\
\text { os alunos ao debate. }\end{array}$ \\
\hline 2 & Características pessoais & $\begin{array}{l}\text { Organização da sala; Retomada de conteúdo; Contação de } \\
\text { história: Menina bonita do laço de fita; Discussão sobre autor, } \\
\text { ilustrador e editora; Dinâmica do Espelho (reconhecer } \\
\text { características pessoais); Leitura de imagens por meio da "Caixa } \\
\text { do livro". }\end{array}$ \\
\hline 3 & Reflexões sobre a cor da pele & $\begin{array}{l}\text { Organização da sala; Retomada de conteúdo; Exibição do vídeo: } \\
\text { Menina bonita do laço de fita; Contação de história: } O \text { lápis cor } \\
\text { de pele do menino marrom; Apresentação da caixa de lápis cor } \\
\text { de pele; Reflexão sobre a cor da pele. }\end{array}$ \\
\hline 5 & Árvore genealógica da família & $\begin{array}{l}\text { Organização da sala; Retomada de conteúdo; Construção da } \\
\text { árvore genealógica; Comparação dos seus traços com os da } \\
\text { família; Montagem de mural com as árvores construídas. }\end{array}$ \\
\hline 6 & Eutorretrato & $\begin{array}{l}\text { Organização da sala; Retomada de conteúdo; Construção do } \\
\text { autorretrato no material no material Ethylene Vinyl Acetate } \\
\text { EVA; Montagem da "colcha de retalhos". } \\
\text { Reflexão sobre a diversidade encontrada na sala de aula; } \\
\text { Exibição do vídeo Dúdú } \text { e o lápis cor de pele. }\end{array}$ \\
\hline
\end{tabular}

Fonte: Elaborado pelas autoras (2020).

Conforme disposto no Quadro 2, nota-se que a Sequência Didática foi desenvolvida com atividades específicas, sendo estruturadas a partir do uso de seis materiais didáticos. Ressaltase que todos os recursos didáticos foram construídos ou selecionados baseando-se nas referências obtidas por meio da revisão sistemática de literatura. Abaixo são descritos detalhes das atividades citadas na Sequência Didática:

- Contação da história "Menina bonita do laço de fita": essa etapa faz o uso da literatura e de representações no estímulo da valorização da beleza negra (SILVA; OLIVEIRA, 2015), bem como permite uma reflexão sobre discursos que reforçam as discriminações e os estereótipos (BENITE et al., 2018).

\section{- Construção de uma caixa com o livro "Menina bonita do laço de fita" para a leitura}

de imagens: de modo a tornar a proposta visual e palpável para as crianças, além de garantir a ludicidade ao mesmo tempo que valoriza a temática. A etapa levou em consideração a falta de recursos como um dos motivos pelos quais as questões étnico-raciais não são trabalhadas em sala de aula (AMÉRICO; LUIZ, 2010; DIAS; CECATTO, 2015; MARQUES, 2017). 
- Seleção de vídeos que tratam do tema para sensibilização e discussão: essa proposta objetivou levar maior conhecimento sobre a Lei aos professores e permitir uma desmistificação das concepções sobre a população negra e a formação do povo brasileiro (GILLAM, 2016; GUIMARÃES, 2015; PEREIRA et al., 2018), visto que, muitas vezes, percebe-se uma conotação exótica e deturpada, da contribuição do seu povo na produção cultural, artística e econômica do nosso país (AMÉRICO, 2014).

- Árvore genealógica para refletir sobre as diferenças por meio de comparação dos traços físicos; e Construção de uma colcha de retalhos de autorretratos (material EVA) para verificação da diversidade encontrada na sala: esses dois pontos foram estabelecidos visando a superar o racismo de maneira contextualizada, com um olhar desperto para si, para a formação familiar e da comunidade, valorizando as características individuais dos sujeitos (DAXENBERGER, 2017; SILVA; OLIVEIRA, 2015).

\section{- Construção de uma bonequinha de pirulito (Menina bonita do laço de fita) para} trabalhar valores humanos: visto que a formação de docentes contribui para o ensino de valores humanos e a superação da discriminação e do racismo em todas as suas formas (CARDOSO et al., 2016; COSTA; CUSTÓDIO, 2015; DAXENBERGER, 2017; FAVACHO et al., 2017; MARTINS, 2016; VIÇOSA; MOREIRA, 2016). Assim, o último produto da Sequência Didática tinha como objetivo promover um momento de reflexão sobre valores tais como amor, respeito e justiça no trabalho com as relações étnico-raciais.

Como todo trabalho desenvolvido com o intuito de melhorar a qualidade do ensino e aprendizagem em sala de aula exige objetivos, rigor e planejamento, estabeleceram-se as seguintes expectativas de aprendizagem para a Sequência Didática proposta: 1) possibilitar aos estudantes o contato com a Literatura Infantil que traz o negro como personagem principal; 2) trabalhar a diversidade étnico-racial, explorando as características de cada um; 3) ampliar a percepção dos estudantes sobre como a sala é composta por pessoas com diversos tons de pele; 4) refletir sobre a valorização do ser humano, independentemente da cor da pele ou etnia; 5) desmistificar concepções de superioridade do branco sobre o negro; e 6) discutir sobre valores humanos, tais como: amor, respeito e justiça.

O minicurso foi executado em 20 horas, com encontros presenciais, nos quais foram discutidas as relações étnico-raciais, a Lei n ${ }^{\circ}$ 10.639/03 e o processo de construção de atividades planejadas. Por último, foi apresentada a Sequência Didática elaborada com o auxílio da 
Literatura Infantil que traz personagens negros como protagonistas, objetivando a socialização de propostas da Lei $n^{\circ} 10.639 / 03$.

\subsection{PERFIL dOS PARTICIPANTES E SEUS CONHECIMENTOS PRÉVIOS}

No primeiro questionário aplicado aos participantes, foram solicitadas as seguintes informações: o curso de graduação e ano de conclusão, se possuía especialização, o local de trabalho (rede de ensino) e o tempo de serviço.

Quanto aos cursos de graduação, foi possível observar que todos os participantes fizeram licenciatura em diversas áreas (Geografia, História, Letras e Pedagogia). No entanto, somente dezesseis professores (69,5\%) são licenciados em Pedagogia, conforme exige a $\mathrm{CNE} / \mathrm{CP} \mathrm{n}^{\circ} 01$ de 15 de maio de 2006 que institui as Diretrizes Curriculares Nacionais para os cursos de graduação em Pedagogia na modalidade de licenciatura. Esta legislação estabelece no artigo $2^{\circ}$ que esses cursos se destinam à formação inicial de professores para o exercício da docência em educação infantil, nos anos iniciais do ensino fundamental, nos cursos de ensino médio na modalidade Normal e em cursos de educação profissional na área de serviços e apoio escolar, assim como em outras áreas que requeiram conhecimentos pedagógicos (BRASIL, 2010). Entre os professores pedagogos, seis $(37,5 \%)$ fizeram o curso como segunda graduação, possivelmente, por estarem atuando nessa modalidade de ensino. Os anos de conclusão ficam entre 1996 e 2017, sendo que a maioria dos professores concluíram a graduação entre 2000 e 2010.

Acerca da especialização, os dados apresentam diversos enfoques na área de Educação (Planejamento Educacional, Administração Escolar, Educação Inclusiva, Gestão Educacional, Coordenação Pedagógica e Planejamento, Alfabetização nas Séries Iniciais, Formação Socioeconômica do Brasil, Alfabetização, Letramento e Inclusão, Psicopedagogia e Literatura Infanto-Juvenil), indicando que 18 professores $(78,3 \%)$ têm se atualizado para além de sua formação inicial (um ou mais cursos de especialização lato sensu).

Entretanto, ressalta-se que nenhum dos respondentes participou de formação continuada na área proposta do curso a ser ministrado. Tal dado enfatiza a incipiente formação de professores para o desenvolvimento da Educação das Relações Étnico-Raciais. Sem dúvida esse aspecto contribui para que situações de preconceito, racismo e discriminação continuem ocorrendo no ambiente escolar. Uma vez que a implementação da Lei favorece o preparo e embasamento de docentes para a lida com essas questões, é essencial que esta seja colocada em prática, a fim de contribuir para o estabelecimento de uma sociedade mais justa e livre de 
preconceitos (ALVES, 2017; EUGÊNIO; SANTANA, 2018; DIAS; CECATTO, 2015; LIRIO, 2015; SILVA, MARQUES, 2015).

No que se refere ao local de trabalho (rede de ensino), 21 professores são da rede municipal de ensino de Pires do Rio e dois professores da rede estadual de ensino de Pires do Rio. Quanto ao tempo de serviço prestado na educação básica, a maioria dos professores tem de 11 a 20 anos de trabalho (52\%), o que revela experiência profissional na educação. De 1 a 10 anos totalizam seis $(26 \%)$ e somente três $(13 \%)$ não declararam. Dois participantes se destacam, um com apenas seis meses de serviço na educação, e outro com mais de 30 anos de atuação.

O segundo recurso aplicado para o levantamento dos dados foi o questionário pré-curso. Desse modo, a fim de diagnosticar o conhecimento dos professores a respeito da Lei Federal $n^{\circ}$ 10.639/03, questionou-se: "Você conhece a Lei Federal n ${ }^{\circ}$ 10.639/03?". Apenas três participantes afirmaram que sim, e os demais (20) desconhecem a Lei. Tal dado corrobora as afirmações presentes em pesquisas realizadas na revisão da presente proposta, as quais demonstram desconhecimento por parte dos professores, o que leva a ações pontuais, descontextualizadas e sem o devido embasamento das diretrizes curriculares (DAXENBERGER, 2017; PEREIRA et al., 2018).

Os números ainda são alarmantes e nos levam a concluir que os educadores não estão trabalhando as determinações da referida Lei. Além disso, é preciso ressaltar que mais da metade dos participantes possui acima de dez anos de atuação, e considerando os 16 anos de existência da Lei, é imprescindível que políticas públicas e propostas de formação continuada sejam implementadas para que haja, de fato, um ensino que discuta o racismo e seus desdobramentos. Afinal, “formar para o combate ao racismo e para a emergência e consolidação de uma sociedade democrática implica, antes de tudo, em saber formar" (COELHO; COELHO, 2018, p. 25).

Além disso, considera-se que, se os educadores não estão sendo preparados, também não conseguirão transmitir essa mensagem imprescindível para a emergência e consolidação de uma sociedade democrática, consciente e que questione discursos que reforçam as discriminações e os estereótipos. Silva e Marques (2015, p. 55), concordam com o exposto ao afirmarem que "os educadores estão saindo das universidades com uma quantidade significativa de conceitos em seus currículos, mas ainda não são suficientes para atuarem de forma satisfatória no que se refere à diversidade no ambiente escolar". 
Quanto ao próximo questionamento: "Você tem conhecimento de que é possível trabalhar a Literatura Infantil na perspectiva da Lei $n^{\circ} 10.639 / 03$ ?”, cerca de $90 \%$ dos participantes afirmaram não ter conhecimento dessa possibilidade, reforçando o argumento para a apresentação da Sequência Didática. O trabalho com a literatura afro-brasileira possibilita a troca de conhecimentos sobre tradições, costumes e cultura por meio do espaço crítico reflexivo da escola (SILVA; OLIVEIRA, 2015). Porém, segundo Jesus e Miranda (2012) a falta de informação e de recursos didáticos, assim como a falta de apoio por parte das Secretarias de Educação para capacitar profissionais, são fatores que dificultam a implementação da Lei $n^{\circ}$ $10.639 / 03$.

Como nosso questionário continha um objetivo exploratório, foi adicionada a penúltima pergunta: "Você conhece algum projeto (atividade pedagógica) que te possibilite trabalhar com a Lei $n^{\circ}$ 10.639/03?'”. Os resultados indicaram que apenas duas participantes conhecem alguma atividade pedagógica com abordagem da cultura afro-brasileira em sala de aula. Reis e Silva (2013) chamam atenção para o fato ao afirmarem ser necessário que a escola esteja atenta à diversidade étnica e cultural e promova intencionalmente práticas pedagógicas que contemplem o tema, especialmente nas séries iniciais. Para tanto, há necessidade de se preparar os professores para trabalharem com a diversidade cultural no ambiente escolar, para que a escola seja transformada em um local em que as diferentes identidades sejam respeitadas e valorizadas (CANEN, XAVIER, 2011).

Sabendo que a matriz curricular é um documento norteador da instituição escolar, definindo os componentes disciplinares a serem ensinados, constituindo o ponto de partida da organização pedagógica e parte integrante do Projeto Político Pedagógico (PPP), os participantes também foram questionados a esse respeito: "Você sabe o que as matrizes curriculares trazem na sua nota de rodapé em relação à Lei $n^{\circ} 10.639 / 03$ ?”. Todos os participantes responderam negativamente a essa questão. Tal dado corrobora as afirmações presentes nas pesquisas de Daxenberger (2017), Pereira et al. (2018) e Silvério et al. (2015), as quais demonstram o desconhecimento da Lei $\mathrm{n}^{\circ} 10.639 / 03$ por parte dos professores, o que conduz na maioria das vezes às iniciativas individuais, ações pontuais, geralmente conduzidas pelos docentes que tiveram alguma formação sobre a ERER.

Ressalta-se que as matrizes curriculares das instituições escolares públicas do Estado de Goiás têm inseridas na nota de rodapé a obrigatoriedade da aplicação da Lei nº 10.639/03 que foi alterada pela Lei $n^{\circ} 11.645 / 08$. É importante salientar que não encontramos a nível municipal 
leis que tratam especificamente da obrigatoriedade do ensino da História e Cultura Afrobrasileira e Africana nas escolas públicas da rede. As demandas referentes à ERER ficam a cargo do cumprimento da Lei no 10.639/03, citada no Regimento Escolar.

\subsection{RESULTADOS DA OBSERVAÇÃO NO DESENVOLVIMENTO DO CURSO E APRESENTAÇÃO DA SEQUÊNCIA DIDÁtica}

Para a aplicação do curso de formação seguiu-se quatro etapas. A primeira foi a preparação do ambiente e inserção da temática aos cursistas. Na segunda houve a apresentação do curso, da Lei, e das matrizes curriculares do Ensino Fundamental ( $1^{\circ}$ a $5^{\circ}$ ano $)$ do Estado de Goiás. Na terceira etapa apresentou-se a Sequência Didática e na última finalizou-se o curso de formação reforçando a necessidade de multiplicação do conhecimento adquirido.

O local para execução do curso foi organizado com exposição de todo o material construído para a apresentação da proposta da Sequência Didática , a saber: 1) os livros de Literatura Infantil contendo a cultura afro-brasileira; 2) a caixa do livro "A menina bonita do laço de fita", de Ana Maria Machado (2011), confeccionada pelas pesquisadoras; 3) uma colcha de retalhos montada com autorretratos; 4) a árvore genealógica para percepção das características individuais; 5) pirulitos decorados com a "Menina bonita do laço de fita" para a realização de um amigo secreto; e 6) caixa de giz de cera cor da pele referente à obra "O lápis cor de pele do menino marrom", de Ana Paula Marini (2018), bem como diversas imagens relativas ao tema e expostas em slides.

$\mathrm{Na}$ primeira etapa, para a integração dos participantes e inserção da temática a ser discutida, a ministrante entregou-lhes uma flor artesanal com mensagens sobre o preconceito racial, as quais foram depositadas dentro de uma jarra com água dando visibilidade a uma frase reflexiva sobre a questão racial. Tal dinâmica abriu o diálogo entre a ministrante e os participantes, sensibilizando-os para a reflexão sobre o negro na sociedade brasileira.

Na segunda etapa, para expor a proposta da Sequência Didática, a ministrante explicitou a metodologia, apresentando referenciais para fundamentar a explicação. Posteriormente, apresentou-se a Lei $\mathrm{n}^{\mathrm{o}} 10.6396 / 03$ e as matrizes curriculares do Ensino Fundamental $\left(1^{\circ}\right.$ a $^{\circ}$ ano) do Estado de Goiás, analisando-as, inclusive a nota de rodapé que traz a obrigatoriedade de implementação da Lei. Foi perceptível que a grande maioria não conhecia a Lei e a obrigatoriedade exigida pelas matrizes no contexto local. Vale ressaltar que, embora o grupo contivesse cinco professoras negras, apenas três disseram conhecer a Lei mencionada. Segundo Dias e Cecatto $(2015$, p. 293) "é importante que ocorra a socialização dos conhecimentos 
referentes à Lei $\mathrm{n}^{\circ} 10.639 / 03$ entre a comunidade escolar e a sociedade", pois o desconhecimento contribui para a não efetivação. Tais observações reforçam que a aprovação da Lei 10.639/2003 não é o suficiente para sua implementação e que se deve oportunizar formação específica para os professores (DIAS; CECATTO, 2015). Sendo assim, estarão seguros e preparados para desmistificar os preconceitos e implantar uma cultura de empatia e igualdade.

Na terceira etapa, foi apresentada a Sequência Didática elaborada. Os participantes estavam animados, pois, fotografaram o material exposto para posterior reprodução, e solicitaram a presença da ministrante em seus locais de trabalho para a contação das histórias. Tal perfil demonstra que, de fato, existe um interesse por parte dos docentes e a percepção da importância da temática. Entretanto, a ausência de materiais que abordem o assunto, assim como a insuficiência e limitação dos recortes obtidos nos livros didáticos, são aspectos que dificultam a consolidação de propostas relacionadas à socialização da Lei (DIAS; CECATTO, 2015).

As discussões subsequentes oportunizaram momentos de fala por parte das cursistas, as quais demonstraram a importância de abordar assuntos relacionados às relações étnico-raciais nas escolas. Uma participante expôs sofrer rejeição por parte dos membros de sua família quanto às suas características físicas e afirmou ser discriminada pela sociedade por sua crença religiosa, sendo caracterizada como "macumbeira" por fazer parte do Candomblé, reforçando o que Freitag e Winkler (2014) expõem quanto à necessidade de ressignificação da cultura negra para os próprios negros e seus descendentes.

Considerando que um dos melhores modos de superar o racismo é valorizar a cultura afro-brasileira, aumentando as representações negras e estimulando a valorização da beleza, da coragem e da história que envolve essas pessoas (CESAR; LIMA, 2018; SILVA; OLIVEIRA, 2015;), e tendo em vista o interesse e participação demonstrado pelos participantes, foi possível perceber que ações como essas podem promover um acréscimo de conhecimento, um reconhecimento da responsabilização e uma mudança de percepção sobre a importância das relações étnico-raciais.

$\mathrm{Na}$ última etapa do curso foi disponibilizada para cada participante a cópia impressa da Sequência Didática e, junto a ela, foi realizado um convite à ação e multiplicação do conhecimento adquirido. 


\subsection{APLICAÇÃo do QUESTIONÁRIO DE AVALIAÇÃo do CURSO E dOS CONHECIMENTOS} ADQUIRIDOS

Após a realização do curso, um questionário (pós-curso) final foi aplicado aos participantes de modo a identificar se, de fato, houve aprendizado e verificar a opinião geral. Os primeiros questionamentos foram idênticos ao questionário anterior (pré-curso). As respostas de todos os participantes foram afirmativas com relação aos três primeiros questionamentos, evidenciando que a formação continuada e a preparação para estabelecer relações entre o conteúdo e o cotidiano social são primordiais para melhorar a qualidade da prática docente (COELHO; SOARES, 2017; DIAS; CECATTO, 2015; MÜLLER; COELHO, 2013).

Após a formação continuada, os participantes compreenderam que a referida Lei pode ser trabalhada com a contribuição da Literatura Infantil, a fim de trazer aos estudantes a valorização e o conhecimento da cultura afro-brasileira. Além disso, os respondentes descobriram que as Sequência Didáticas, bem como os materiais lúdicos, podem auxiliar nos processos de ensino e aprendizagem da temática.

Como relatado em nossa metodologia, três questões em escala Likert foram adicionadas ao último questionário (pós-curso), com o objetivo de avaliar o curso e as possibilidades de aplicação da Sequência Didática em sala de aula. Ao item da escala "o conteúdo trabalhado na Sequência Didática é importante", apenas um participante afirmou que concordava parcialmente, os demais assinalaram que concordavam totalmente com a afirmação. Ao item “é possível trabalhar a Sequência Didática apresentada nas salas de $4^{\circ}$ e $5^{\circ}$ anos?”, todos os participantes afirmaram concordar totalmente. Por fim, ao serem questionadas se estavam satisfeitas com a Sequência Didática, 22 participantes concordaram totalmente. Entretanto, uma delas assinalou também o ponto "concordo parcialmente", com a seguinte justificativa: "só poderíamos ter mais tempo", "a gente precisa de mais formações como essa”.

Tal resposta reforça ser essencial para o docente ter formação continuada permanente e em tempo adequado, a fim de que o processo ensino e aprendizagem seja mais efetivo. Nesse caso, quanto à aplicação da Lei $\mathrm{n}^{\circ} 10.639 / 03$, pesquisas recentes demonstram ser a iniciativa ainda mais necessária (CARDOSO et al., 2016; COSTA; CUSTÓDIO, 2015; DAXENBERGER, 2017; FAVACHO et al., 2017; MARTINS, 2016).

O nível de concordância a todas as afirmações demonstra que as atividades das Sequências Didáticas evidenciaram com clareza a possibilidade do uso da Literatura Infantil 
para trabalhar a História da África e dos afro-brasileiros para alunos das séries iniciais do Ensino Fundamental. A partir dos resultados é possível concluir que os objetivos deste estudo foram atingidos e que as ações pedagógicas nessa área devem ser cuidadosamente planejadas e executadas, de modo a garantir o conhecimento necessário a professores e alunos, a fim de subsidiá-los na construção de sua identidade individual e coletiva. Conforme assegurado por Coelho (2000), Zilberman (2003) e Perissé (2006), a Literatura Infantil foi, de fato, uma aliada poderosa no diálogo dos alunos com a cultura afro-brasileira no seu processo formativo. Além disso, a metodologia das Sequências Didáticas possibilitou a organização de atividades que contemplaram conteúdos conceituais, procedimentais e atitudinais (ZABALA, 1998).

\section{CONSIDERAÇÕES FINAIS}

A revisão sistemática permitiu identificar que, após 16 anos da Lei n 10.639/03, ainda existem lacunas na formação inicial e que muitos docentes estão despreparados para lidar com as relações étnico-raciais. Além da abordagem superficial e enviesada de muitos livros didáticos, a escassez de recursos apresentada pelas pesquisas e o parco foco no Ensino Fundamental foram estímulos para o desenvolvimento do curso e da Sequência Didática para facilitar a inclusão da história e cultura afro-brasileira e africana na educação básica.

Os dados coletados antes do curso comprovaram o desconhecimento dos cursistas sobre a Lei e o estudo da cultura afro-brasileira no cotidiano escolar, conforme também apontado pela literatura. O que confirma que o desconhecimento é uma das dificuldades para a efetivação de políticas públicas referentes à diversidade cultural.

Entretanto, os dados levantados durantes e após a ação revelaram o quanto a formação continuada foi de suma importância para que os docentes estivessem mais qualificados para a prática pedagógica em sala de aula. É fundamental e relevante o processo de formação de professores para atuar com as questões étnico-raciais, tanto no contexto da formação inicial quanto na continuada, e que essa última deve ser permanente e contínua, a fim de possibilitar ao docente seu crescimento profissional e pessoal. Deste modo, se há maior qualificação no fazer pedagógico relacionado às relações étnico-raciais, será possível criar condições para um ensino comprometido com a diversidade cultural.

Por fim, a conclusão apresentada por outros pesquisadores se mantém: há necessidade de uma política pública eficiente de formação continuada para os professores da rede pública de ensino em relação à Lei $n^{\circ} 10.639 / 03$ e sua aplicabilidade. Os dados de nossa pesquisa evidenciam que a formação continuada nessa área precisa ser fomentada, para que a educação 
cumpra seu papel na articulação de aspectos políticos e pedagógicos em um currículo comprometido com a valorização da diversidade.

\section{REFERÊNCIAS}

ALENCAR, Edvonete Souza de; ALMOULOUD, Saddo Ag. A Metodologia de Pesquisa: Metassíntese Qualitativa. Revista Reflexão e Ação, Santa Cruz do Sul, v. 25, n. 3, p. 204220. http://dx.doi.org/10.17058/rea.v25i3.9731

ALMEIDA, Silvio Luiz. O que é racismo estrutural? Belo Horizonte: Letramento, 2018.

ALVES, Marta Mariano. Lei 10.639/03, formação docente e NEABs: a democratização do currículo como um desafio para a educação brasileira. Cadernos do Aplicação, Porto Alegre, v. 30, p. 33-47, 2017. https://doi.org/10.22456/2595-4377.68405

ALVES-BRITO, Alan; BOOTZ, Vitor Eduardo Buss; MASSONI, Neusa Teresinha. Uma sequência didática para discutir as relações étnico-raciais (Leis 10.639/03 e 11.645/08) na educação científica. Caderno Brasileiro de Ensino de Física, Florianópolis, v. 35, n. 3, p. 917-955, 2018. http://dx.doi.org/10.5007/2175-7941.2018v35n3p917

AMÉRICO, Márcia Cristina. Formação de professores para a implementação da lei 10.639/2003: o ensino da história e cultura afro-brasileira e indígena no currículo escolar.

Poiésis, Niterói, v. 8, n. 1, p. 515-534, 2014.

http://dx.doi.org/10.19177/prppge.v8e142014515-534

AMÉRICO, Márcia Cristina; LUIZ, Viviane. Formação de professores em uma perspectiva multirracial: a lei n. 10.639 e as contribuições para a consolidação de uma autoimagem negra positiva. Revista Eletrônica do Grupo de Pesquisa identidade!, São Leopoldo, v. 15, n. 2, p. 88-97, 2010. Disponível em: http://www.est.edu.br/periodicos/index.php/identidade. Acesso em: 14 jan. 2019.

BENITE, Anna Maria Canavarro; BASTOS, Morgana Abranches; VARGAS, Regina Nobre; FERNANDES, Fernanda Silva; FAUSTINO, Gustavo Augusto Assis. Cultura africana e afrobrasileira e o ensino de química: estudos sobre desigualdades de raça e gênero e a produção científica. Educação em Revista, Belo Horizonte, v. 34, 2018. https://doi.org/10.1590/01024698193098

BRASIL. Lei no 10.639/2003, de 9 de janeiro de 2003. Brasília: MEC, 2003. Disponível em: http://www.planalto.gov.br/ccivil_03/Leis/2003/L10.639.htm. Acesso em: 14 jan. 2019.

BRASIL. Lei no 11.645, de 10 março de 2008. Brasília: MEC, 2008. Disponível em: http://www.planalto.gov.br/ccivil_03/_ato2007-2010/2008/lei/111645.htm. Acesso em: 14 jan. 2019.

BRASIL. Diretrizes Curriculares Nacionais para a Educação Infantil. Brasília: MEC, 2010. Disponível em:

http://portal.mec.gov.br/index.php?option=com docman\&view=download\&alias=9769diretrizescurriculares-2012\&category_slug=janeiro-2012-pdf\&Itemid=30192. Acesso em: 05 out. 2019. 
CANEN, Ana; XAVIER, Giseli Pereli de Moura. Formação continuada de professores para a diversidade cultural: ênfases, silêncios e perspectivas. Revista Brasileira de Educação, Rio de Janeiro, v. 16, n. 48, p. 641-661, set./dez. 2011. http://dx.doi.org/10.1590/S141324782011000300007

CARDOSO, Ivanilda Amado; CASTRO, Rosane Michele de. Absence / presence of the ethnic- racial relations in curriculum of the course pedagogy: the case of Unesp/ Marilia. Revista Praxis Educacional, Vitória da Conquista, v. 11, n. 18, p. 91-116, 2015. http://hdl.handle.net/11449/165959

CARTH, John Land. A Base Nacional Comum Curricular e a aplicação da política de Educação para Educação das Relações Étnico-Raciais (afro-brasileira, quilombola, cigana). Brasília, 2017. Disponível em: http://etnicoracial.mec.gov.br/images/pdf/artigos/ABNCC2018-e-aERER.pdf. Acesso em: 20 out. 2019.

CESAR, América Lucia Silva; LIMA, Maria Nazaré Mota de. Letramentos e Etnografias na Escola: Diálogos Inter/Transculturais na Educação Antirracismo. Línguas \& Letras, Cascavel, v. 19, n. 44, p. 168-182, 2018. https://doi.org/10.5935/1981-4755.20180031

COELHO, Mauro Cezar; COELHO, Wilma de Nazaré Baía. Os conteúdos étnico-raciais na educação brasileira: práticas em curso. Educar em Revista, Curitiba, n. 47, p. 67-84, 2013. https://doi.org/10.1590/S0104-40602013000100006

COELHO, Mauro Cezar; COELHO, Wilma de Nazaré Baía. As licenciaturas em história e a lei 10.639/03: percursos de formação para o trato com a diferença? Educação em Revista, Belo Horizonte, v. 34, 2018. Disponível em: http://www.scielo.br/pdf/edur/v34/1982-6621edur-34-e192224.pdf. Acesso em: 05 ago. 2019. https://doi.org/10.1590/0102-4698192224

COELHO, Nelly Novaes. Literatura infantil: teoria, análise, didática. São Paulo: Moderna, 2000 .

CARDOSO, Paulino de Jesus Francisco; CARVALHO, Simone Barboza de; RASCKE, Karla Leandro; SANTOS, Carina Santiago dos; SILVA, Cristiane Mare da. Formação continuada em educação das relações étnico-raciais: o(a) professor(a) tutor(a) na construção do conhecimento. Revista Ibero-Americana de Estudos em Educação, Araraquara, v. 11, n. 3, p. 1389-1408, out. 2016. https://doi.org/10.21723/riaee.v11.n3.8018

COELHO, Wilma de Nazaré Baía; SOARES, Nicelma Josenila Britos. Formação Continuada de Professores: as Ações da Universidade e a Lei n. 10.639/2003. Cadernos de Pesquisa: Pensamento Educacional, Curitiba, v. 12, n. 31, 2017. https://doi.org/10.35168/21752613.UTP.pens_ed.2017.Vol12.N31.pp141-156

COSTA, Alexandre Emboaba da. Training educators in anti-racism and pluriculturalismo: recent experiences from Brazil. Race Ethnicity and Education, v. 19, n. 1, p. 23-45, 2014. https://doi.org/10.1080/13613324.2014.946488

COSTA, Célia Souza da; CUSTÓDIO, Elivaldo Serrão. A Lei n 10.639/2003 no âmbito escolar: os avanços e entraves do Núcleo Estadual de Educação Étnico Racial no Amapá. Identidade! São Leopoldo, v. 20, n. 1, p. 64-77, 2015. Disponível em: http://www.est.com.br/periodicos/index.php/identidade/article/viewFile/2435/2389. Acesso 
em: 05 ago. 2019.

DALMORO, Marlon; VIEIRA, Kelmara Mendes. Dilemas na construção de escalas Tipo Likert: o número de itens e a disposição influenciam nos resultados? Revista Gestão Organizacional, Chapecó, v. 6, n. 3, p. 161-174, 2013. https://doi.org/10.22277/rgo.v6i3.1386

DAXENBERGER, Ana Cristina Silva. As questões étnico-raciais em escolas estaduais na região do brejo paraibano. Revista on line de Política e Gestão Educacional, Araraquara, v. 21, n. 2, p. 363-382, 2017. http://dx.doi.org/10.22633/rpge.v21.n.2.2017.9982

DIAS, Ednalva da Conceição; CECATTO, Adriano. Entre teoria e prática: a formação docente e a apropriação da lei 10.639/2003 no cotidiano escolar. História \& Ensino, Londrina, v. 21, n. 2, p. 283-306, 2015. http://dx.doi.org/10.5433/2238-3018.2015v21n2p283

DÚDÚ E O LÁPIS COR DE PELE. Direção: Miguel Rodrigues. Take a Take Films, 2018. (18 min.). Disponível em: https://www.youtube.com/watch?v=-VGpB_8b77U. Acesso em: 24 abr. 2019.

EUGÊNIO, Benedito Gonçalves; SANTANA, Fabiana. Relações étnico-raciais e o trabalho com a Lei 10.639/03: análise de uma experiência com formação docente. Ensino \& Pesquisa, União da Vitória, v. 33, n. 2, p. 47-56, 2018. Disponível em:

http://periodicos.unespar.edu.br/index.php/ensinoepesquisa/article/view/1102. Acesso em: 06 ago. 2019.

FAVACHO, Maricelma da Cruz; VIDEIRA, Piedade Lino; CUSTÓDIO, Elivaldo Serrão. O processo de implantação da Lei n ${ }^{\circ} 10.639 / 2003$ numa Escola Municipal, localizada na Comunidade Negra do Coração na cidade de Macapá / Amapá. Identidade!, São Leopoldo, v. 22, n. 1, p. 27-4, 2017. Disponível em:

http://www.periodicos.est.edu.br/index.php/identidade/article/viewFile/3043/2882. Acesso em: 07 de ago. 2019.

FERNANDES, Florestan. O negro no mundo dos brancos. São Paulo: Global Editora, 1972.

FREITAG, Suzeli Adriane; WINKLER, Andréa Denise. O negro e a literatura infantil.

Interfaces: Educação e Sociedade, v. 1, n. 1, p. 101-115, 2014. Disponível em:

https://core.ac.uk/download/pdf/229767759.pdf. Acesso em: 08 de ago. 2019.

GARCIA, Alessandra Agenor de Moura; SILVA, Marcio Pereira da; ALEXANDRE, Ivone Jesus. Desafios e perspectivas na formação de professores e a Lei 10.639/03. Revista Eventos Pedagógicos, Cáceres, v. 3, n. 2, p. 282-290, 2012. Disponível em:

http://sinop.unemat.br/projetos/revista/index.php/eventos/article/download/672/480. Acesso em: 05 ago. 2019.

GILLAM, Reighan. Learning to Transgress: Law 10.639 and Teacher-Training Classrooms in São Paulo, Brazil. Transforming Anthropology, v. 24, n. 1, p. 70-79, 2016. https://doi.org/10.1111/traa.12058

GODOY, Eliete Aparecida de. A ausência das questões raciais na formação inicial de professores e a Lei 10.639/03. Revista de Educação PUC, Campinas, v. 22, n. 1, p. 77-92, 


\section{7. https://doi.org/10.24220/2318-0870v22n1a3433}

GUIMARÃES, Selva. The teaching of Afro-Brazilian and indigenous culture and history in Brazilian basic education in the 21st century. Policy Futures in Education, v. 13, n. 8, p. 939-948, 2015. https://doi.org/10.1177/1478210315579980

FOLHA DE SÃO PAULO. Jornal, São Paulo. Disponível em:

https://www1.folha.uol.com.br/educacao/2019/09/4-em-cada-10-jovens-negros-naoterminaram-o-ensino-medio.shtml. Acesso em: 02 out. 2019.

JESUS, Rodrigo Ednilson de; MIRANDA, Shirley Aparecida de. O processo de institucionalização da lei no 10.639/03. In: GOMES, Nilma Lino. (Org.). Práticas pedagógicas de trabalho com relações étnico-raciais na escola na perspectiva da Lei $\mathbf{n}^{\mathbf{o}}$ 10.639/03. Brasília: MEC; Unesco, 2012.

LIMA, Eduardo; SOUZA, Rosely Tavares de. Violência simbólica e as relações étnicoraciais. Revista Humanidades e Inovação, Palmas, v. 4, n. 2, p. 1-9, 2016. Disponível em: https://revista.unitins.br/index.php/humanidadeseinovacao/article/view/173. Acesso em $10 \mathrm{de}$ ago. 2019.

LIRIO, Carlos José. Alegações sobre mídia digital no âmbito da lei federal 10.639/2003, Consciência linguística crítica e formação docente. Muitas Vozes, Ponta Grossa, v. 4, n. 1, p. 11-25, 2015. https://doi.org/10.5212/MuitasVozes.v.4i1.0001

MACHADO, Ana Maria. Menina bonita do laço de fita. 7. ed. São Paulo: Ática, 2011.

MARCONI, Marina de Andrade; LAKATOS, Eva Maria. Técnicas de pesquisa. 8. ed. São Paulo: Atlas, 2018.

MARINI, Ana Paula. O lápis cor de pele do menino marrom. São Paulo: Autografia, 2018.

MARQUES, Eugenia Portela de Siqueira. A implementação da lei 10.639/2003 no estado de Mato Grosso do Sul e a formação continuada de professores: uma perspectiva emancipatória e decolonial. Revista Contemporânea de Educação, Rio de Janeiro, v. 12, n. 23, p. 51-68, 2017. https://doi.org/10.20500/rce.v12i23.3248

MARTINS, Edna. Racismo e educação: a temática étnico-racial em foco em uma Universidade pública. Interfaces Brasil/Canadá, v. 16, n. 2, p. 89-112, 2016. http://dx.doi.org/10.15210/interfaces.v16i2.7466

MATHEUS, Maria Clara Cassuli. Metassíntese qualitativa: desenvolvimento e contribuições para a prática baseada em evidências. Acta Paul Enferm, v. 22, n. 1, p. 543-545, 2009. https://doi.org/10.1590/S0103-21002009000800019

MENINA BONITA DO LAÇO DE FITA. Direção: Diego Lopes e Cláudio Bitencourt. Produção: Oger Sepol Produções. 2014. (7min.21s.). Disponível em:

https://www.youtube.com/watch?v=UhR8SXhQv6s. Acesso em: 24 abr. 2019.

MÜLLER, Tânia Mara Pedroso; COELHO, Wilma de Nazaré Baía. A Lei nº 10.639/03 e a formação de professores: trajetória e perspectivas. Revista da Associação Brasileira de 
Pesquisadores/as Negros/as, Goiânia, v. 5, n. 11, p. 29-54, 2013. Disponível em: https://tinyurl.com/du7nttpf. Acesso em 15 de ago. 2019.

OLIVEIRA, Elânia de. A Lei 10.639/2003 e a Escola de Educação Especial: um desafio a mais para a formação de professores. Educar em Revista, Curitiba, n. 47, p. 85-95, 2013. https://doi.org/10.1590/S0104-40602013000100007

OLIVEIRA, Míria Gomes de; SILVA, Paulo Vinícius Baptista da. Educação Étnico-Racial e Formação Inicial de Professores: a recepção da Lei 10.639/03. Educação e Realidade, Porto Alegre, v. 42, n. 1, p. 183-196, 2017. http://dx.doi.org/10.1590/2175-623661123

PAULA, Benjamim Xavier de; GUIMARAES, Selva. 10 anos da lei federal no 10.639/2003 e a formação de professores: uma leitura de pesquisas científicas. Educação e Pesquisa, São Paulo, v. 40, n. 2, p. 435-448, 2014. https://doi.org/10.1590/S1517-97022014061517

PEIXOTO, Fabiana de Lima. Literatura Afro-brasileira. Salvador: FFCH/UFBA, 2013.

PEREIRA, Arliene Stephanie Menezes; GOMES, Daniel Pinto; CARMO, Klertianny Teixeira do; SILVA, Eduardo Vinicius Mota. Aplicação das leis 10.639/03 e 11.645/08 nas aulas de educação física: diagnóstico da rede municipal de Fortaleza/CE. Revista Brasileira de Ciências do Esporte, Porto Alegre, n. 41, n. 4, p. 1-7. 2018. https://doi.org/10.1016/j.rbce.2018.06.004

PERISSÉ, Gabriel. Literatura e educação. Belo Horizonte: Autêntica, 2006.

REIS, Wilma Jacyere Silva dos; SILVA, Teresa Cristina. A Literatura Infantil nos Anos Iniciais: a questão racial e o preconceito na sala de aula. In: Anais III ENID. v. 1, 2013. Disponível em: https://editorarealize.com.br/artigo/visualizar/4856. Acesso em: 15 de out. 2019.

RODRIGUES, Auro de Jesus. Metodologia Científica. São Paulo: Avercamp, 2006.

RODRIGUES, Tatiane Consentino; OLIVEIRA, Fabiana Luci de; SANTOS, Fernanda Vieira da Silva. Desafios da implementação da lei no 10.639/03: um estudo de caso de municípios do Estado de São Paulo. Revista Educação, Campinas, v. 21, n. 3, p. 281-294, set./dez. 2010. https://doi.org/10.24220/2318-0870v21n3a3435

SILVA, Wilker Solidade; MARQUES, Eugenia Portela Siqueira. Educação e relações étnicoraciais: a Lei 10.639/03, a formação docente e o espaço escolar. Horizontes, Itatiba, v. 33, n. 2, p.47-56, 2015. https://doi.org/10.24933/horizontes.v33i2.296

SILVA, Andressa Carvalho; OLIVEIRA, Paula Cristina Silva de. Ressignificação da identidade negra em uma escola no Distrito de Sopa, Diamantina-MG. Olh@res, São Paulo, v. 3, n. 1, p. 258-279, 2015. https://doi.org/10.34024/olhares.2015.v3.358

SILVA, Jeusamir Alves da. Da história negada a luta por uma visibilidade igualada. Revista Periferia, Rio de Janeiro, v. 10, n. 1, p. 202-212, 2018.

https://doi.org/10.12957/periferia.2018.31155

SILVA, Wilker Solidade; MARQUES, Eugenia Portela Siqueira. Educação e relações étnico- 
raciais: a Lei 10.639/03, a formação docente e o espaço escolar. Horizontes, Itatiba, v. 33, n. 2, p. 47-56, 2015. https://doi.org/10.24933/horizontes.v33i2.296

SILVÉRIO, Valter Robério; RODRIGUES, T. C.; DOMINGUES, A. C. Diretrizes Curriculares e Plano Nacional de Implementação da Lei n ${ }^{\circ} 10.639 / 2003$ : balanço de implementação, desafios e perspectivas. In: Ação Educativa Assessoria Pesquisa e Informação. Educação das Relações Raciais: balanços e desafios da implementação da lei 10.639/2003. São Paulo, 2015.

SMITH, Christian; DENTON, Melinda Lundquist. Methodological issues and challenges in the study of american youth and religion. Department of Sociology: University of North Carolina at Chapel Hill, 2001. Disponível em:

https://youthandreligion.nd.edu/assets/102503/methodological issues and challenges in the _study_of_american_youth_and_religion.pdf. Acesso em: 15 de nov. 2019.

STRAND, Jennifer; OLIN, Elisabeth; TIDEFORS, Inga. Mental health professionals' views of the parents of patients with psychotic disorders: A participant observation study. Health \& Social Care In The Community, v. 23, n. 2, p. 141-149, 2015.

https://doi.org/10.1111/hsc.12122

SULEIMAN, Bianca Barbosa. Psicologia e Ensino das Relações Étnico-Raciais: uma experiência na formação de professores. Psicologia Escolar e Educacional, São Paulo, v. 18, n. 2, p. 369-372, ago. 2014. https://doi.org/10.1590/2175-3539/2014/0182809

JÚNIOR TAVARES, Fernando; MONT'ALVÃO, Arnaldo; NEUBERT, Luiz Flávio. Rendimento escolar e seus determinantes sociais no Brasil. Revista Brasileira de Sociologia, v. 3, n. 6, p. 117-137, 2015. http://dx.doi.org/10.20336/rbs.123

TEIXEIRA, Paulo Marcelo Marini; MEGID NETO, Jorge. O estado da arte da pesquisa em ensino de Biologia no Brasil: um panorama baseado na análise de dissertações e teses.

Revista Electrónica de Enseñanza de las Ciencias, Lagoas-Marcosende, v. 11, n. 2, p. 273 297, 2012. Disponível em:

http://reec.uvigo.es/volumenes/volumen11/REEC_11_2_2_ex500.pdf. Acesso em 19 de out. 2019.

VIÇOSA, Vanessa Lana; MOREIRA, Danilo Araújo. A lei 10.639/2003 e o ensino de história: reflexões a partir dos espaços de formação de professores. Instrumento: Revista de Estudo e Pesquisa em Educação, Juíz de Fora, v. 18, n. 2, p. 1-9, 2016. Disponível em: https://periodicos.ufjf.br/index.php/revistainstrumento/article/view/18992. Acesso em: $20 \mathrm{de}$ out. 2019.

VOSGERAU, Dilmeire Sant'Anna Ramos; ROMANOWSKI, Joana Paulin. Estudos de revisão: implicações conceituais e metodológicas. Revista Diálogo Educacional, v. 14, n. 41, p. 165-189, 2014. http://dx.doi.org/10.7213/dialogo.educ.14.041.DS08

ZABALA, Antoni. A prática educativa: como ensinar. Porto Alegre: Artmed, 1998.

ZILBERMAN, Regina. A literatura infantil na escola. 11. ed. São Paulo: Global, 2003. 